$\gamma$

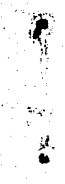

Idaho

National

Engineering

Laboratory

Managed

by the U.S.

Department

of Energy
EGG-WTD-9672

September 1991

INFORMAL REPORT

Technical Baseline Description for In Situ Vitrification Laboratory Test Systems

K. V. Beard

R. W. Bonnenberg

L. R. Watson 


\section{TECHNICAL BASELINE DESCRIPTION \\ FOR IN SITU VITRIFICATION \\ LABORATORY TEST EQUIPMENT}

Project No. 015430

K. V. Beard

R. W. Bonnenberg

L. R. Watson

Published September 1991

Idaho National Engineering Laboratory

EG\&G Idaho, Inc.

Idaho Falls, Idaho 83415

Prepared for the

U.S. Department of Energy

Office of Environmental Restoration and Waste Management Under DOE Contract No. DE-AC07-76ID01570 
TECHNICAL BASELINE DESCRIPTION FOR IN SITU VITRIFICATION LABORATORY TEST SYSTEMS

EGG-WTD- 9672

September 1991

Approved By:

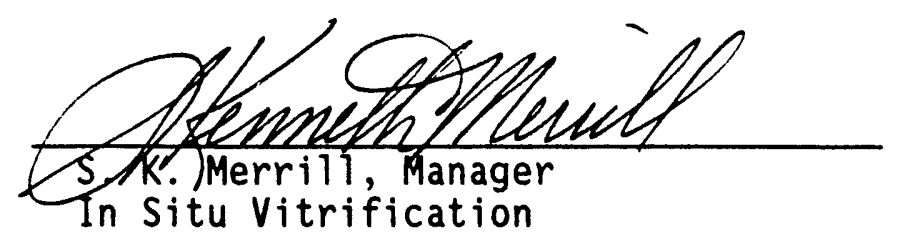

Date: $9 / 12 / 91$
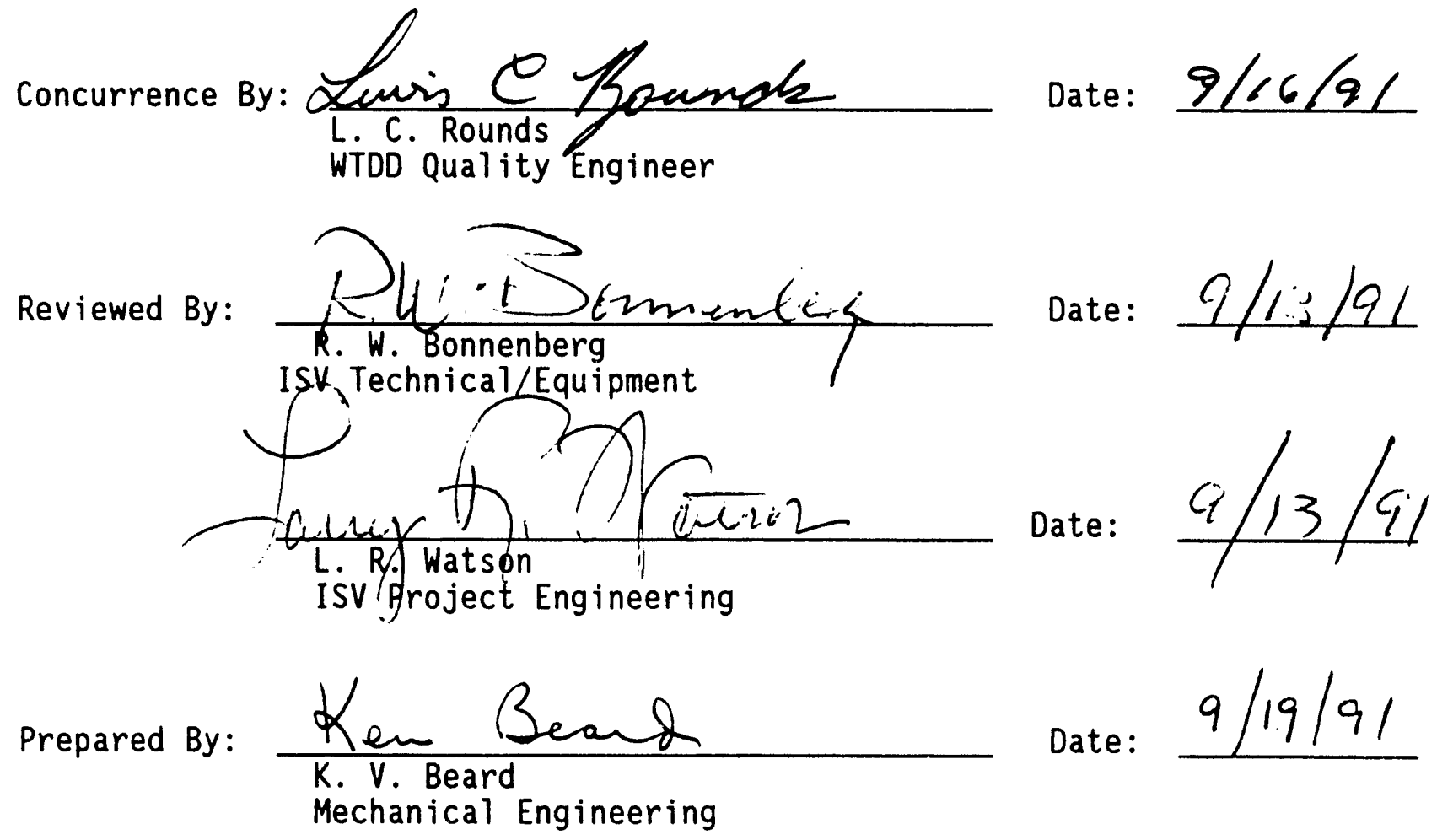

Date: $9 / 19 / 91$ 
In situ vitrification (ISV) has been identified as a possible waste treatment technology. ISV was developed by Pacific Northwest Laboratory (PNL), Richland, Washington, as a thermal treatment process to treat contaminated soils in place. The process, which electrically melts and dissolves soils and associated inorganic materials, simultaneously destroys and/or removes organic contaminants while incorporating inorganic contaminants into a stable, glass-like residual product.

A PNL spin-off company, Geosafe Corporation located in Kirkland, Washington, was formed to develop ISV technology for the commercial sector. Much of the ISV engineering work has been done in a cooperative effort between Geosafe and PNL and, since 1989, the Idaho National Engineering Laboratory (INEL). A small laboratory test model designed by Geosafe, called "engineering-scale model," was obtained by EG\&G Idaho, Inc., from Geosafe. This equipment arrived at the INEL in early November 1990. Subsequent to installation at Test Area North (TAN)-633 of the original Geosafe equipment, significant design modifications took place to improve safe operation of the Geosafe laboratory test model. The modifications make the equipment consistent with its planned use and mission at INEL. It is anticipated that 12-18 laboratory tests will be conducted in FY-91.

This Technical Baseline Description has been prepared to provide high level descriptions of the design of the Laboratory Test model, including all design modifications and safety improvements made to date. Furthermore, the Technical Baseline Description provides a basic overview of the interface documents for configuration management, program management interfaces, safety, quality, and security requirements. 


\section{FOREWORD}

In situ vitrification (ISV) is a process in which potentially hazardous, buried waste forms and the surrounding soil are fused in place into a stable, glass-like material. Melting of the buried waste and the nearby soil is accomplished by establishing an electric current between electrodes inserted in the soil. Dissipation of electrical energy through the soil between the electrodes creates temperatures high enough to melt the soil. The molten zone continues to grow and encompass the waste as long as sufficient power is supplied. The glass-like material that is formed in the vitrification process is extremely durable. Radioactive and hazardous wastes are encapsulated by this material and are thereby kept from migrating throughout the environment. Also, organic wastes are pyrolyzed by the high temperatures created in the vitrification process.

The ISV process was developed at Pacific Northwest Laboratories (PNL), a division of Battelle Memorial Institute, for the Department of Energy. To commercialize the process, PNL developed a start-up company known as Geosafe Corporation that employs several people instrumental in developing ISV technology at PNL. Geosafe has experimented with ISV processes and has developed equipment systems for ISV testing purposes. In particular, Geosafe has an engineering-scale system located at the University of Washington and has conducted several tests with that equipment.

The Idaho National Engineering Laboratory (INEL) has recently begun an ISV testing program. In April 1990, EG\&G Idaho, Inc., distributed to various companies a Request for Proposal Authorization (RFPA) to provide ISV engineering equipment. Geosafe responded to that RFPA with a proposal for provision of an engineering-scale equipment test assembly and related documentation. This equipment was procured and has been installed at Test Area North (TAN) on the INEL Site. Subsequent safety analyses on this system indicated that the system needed to be modified by adding a secondary containment and off-gas system before testing could begin. These modifications are in the process of completion at the present time. 
This equipment will be used to obtain test data which will be incorporated into EG\&G Idaho ISV process mathematical models. These models can then assist in bounding the risk of applying ISV systems to locations at the Subsurface Disposal Area at the Radioactive Waste Management Complex at INEL.

The "engineering-scale" description for the Geosafe-furnished small ISV experimental system, which is room-size and designed for a laboratory testing environment, is perceived at INEL as sufficiently permissive to convey abstraction of larger engineering test projects common at INEL. Therefore, the term "engineering-scale" has recently been replaced by "laboratory test equipment." The rest of the report will refer to the equipment as laboratory equipment. 
ABSTRACT

FOREWORD

ACROYMNS

ix

1. SCOPE . . . . . . . . . . . . . . . . . . . . . . 1

2. DESIGN DESCRIPTION . . . . . . . . . . . . . . . . . . 2

2.1 Electrical Power Unit . . . . . . . . . . . . . . 2

2.2 Electrodes and Feed Mechanism . . . . . . . . . . . . . 2

2.3 Confinement ...................... . . 4

2.4 Inlet Air Line . . . . . . . . . . . . . . . . . . . 4

2.5 Primary Off-Gas Line . . . . . . . . . . . . . . . . 5

2.5.1 Plenum ..................... 5

2.5.2 Sampling Ports... . . . . . . . . . . . . . . 5

2.5.3 Condenser . . . . . . . . . . . . . . . . . . . 7

2.5.4 Condensate Collection Tank. . . . . . . . . . . . 7

2.5 .5 Bypass Line .................... . 7

2.5 .6 Blower ...................... . 8

2.5.7 Exhaust stack ................... . 8

2.6 Secondary Off-Gas Line . . . . . . . . . . . . . . . . 8

2.7 Installation ................... . . 8

2.8 Instrumentation . . . . . . . . . . . . . . . . . 10

2.9 Electrode Feed Control Panel . . . . . . . . . . . . . 10

2.10 Documentation .................... 12

3. CONFIGURATION MANAGEMENT . . . . . . . . . . . . . . . . . . . . . 14

4. PROGRAM MANAGEMENT INTERFACES . . . . . . . . . . . . . . . . . . 16

4.1 ISV Laboratory Tests Support Documentation . . . . . . . . . . 16

4.1.1 Security Plan ................... 16

4.1.2 Quality Program Plan . . . . . . . . . . . . . . 16

4.1.3 Technical Plan ................... . 18

4.1.4 Fire Protection Plan . . . . . . . . . . . . . . . . 18

4.1.5 Operating Documentation ............... 18

4.1.6 Tenants Manual .. . . . . . . . . . . . . . . . . . 18

4.1.7 Program Directives... . . . . . . . . . . . . . . 18

4.1.8 Safety Documents .................. . . . 19 
4.1.9 Health and Safety Plan ................ 19

4.1.10 Engineering Documents .. . . . . . . . . . . . . . 19

4.1.11 Training Program Plan ................ . 19

4.1.12 Environmental Documents............. . 20

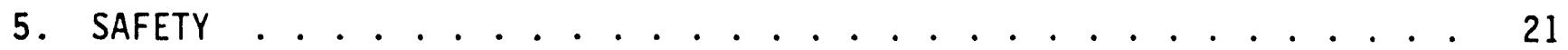

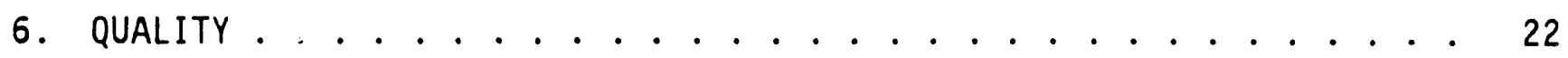

6.1 Organizational Responsibilities .......... 22

6.2 Quality Program Elements.............. 25

7. CONDUCT OF OPERATIONS MATRIX .................. 27

\section{FIGURES}

1. Engineering scale system schematic ............. 3

2. Laboratory ISV process schematic . . . . . . . . . . . . 6

3. HCA Room 9 ISV equipment arrangement ............ . 9

4. ISV electrical schematic ................ 11

5. Project management document interface ............. 17

6. Organizational interface for lab test operations . . . . . . . 23

7. Waste Technology Development Department organizational chart . . . 24

8. Company quality program matrix ............... 26 


\section{ACROYMNS}

$A C$

a)ternating current

DAS data acquisition system

DOE Department of Energy

DOP Detailed Operating Procedures

EPA Environmental Protection Agency

ERP Environmental Restoration Program

FCF Facility Change Form

FSAR Final Safety Analysis Report

HEPA high-efficiency particulate air filter

INEL Idaho National Engineering Laboratory

ISV in situ vitrification

PNL Pacific Northwest Laboratory

PSR Operational Safety Requirements

PVC polyvinyl chloride

QPP Quality Program Plan

RFPA Request for Proposal Authorization

SOP Standard Operating Procedrues

SPCC Spill Controls Countermeasures Plan

SWR Site Work Requests

TAN Test Area North

THS Tan Hot Shop

WMTO Waste Management TAN Operations

WTDD Waste Technology Development Department 


\section{TECHNICAL BASELINE DESCRIPTION \\ FOR IN SITU VITRIFICATION \\ LABORATORY TEST SYSTEMS}

\section{SCOPE}

This document provides a design and performance description of in situ vitrification (ISV) laboratory test equipment procured from Geosafe Corporation and modified by EG\&G Idaho, Inc. It also provides details for installation of the equipment. The information in this document has been distilled from the Geosafe proposal, engineering drawings supplied with the equipment by Geosafe, and EG\&G Idaho engineering drawings that were developed for the modifications. 


\section{DESIGN DESCRIPTION}

Figure 1 provides a schematic of the engineering-scale system as it was procured from Geosafe. The ISV engineering-scale piping and instrumentation diagram (EG\&G Drawing \#438276) provides a schematic diagram of the laboratory test equipment as modified by EG\&G Idaho. Individual components and subsystems of the modified system are described below. Final arrangenent of the laboratory test equipment installed in Room 9 of Test Area North (TAN) -633 is discussed in Section 2.7 .

\subsection{Electrical Power Unit}

The electrical power unit is a $26 \mathrm{~kW}$ Scott Tee transformer with a threephase $208 \mathrm{~V}$ alternating current $(A C)$ input and a two-phase variable voltage $A C$ output to the electrodes. The transformer is equipped with 12 tap positions, which can vary the voltage from 0 to $348 \mathrm{~V}$ per phase, with a maximlin current of $302 \mathrm{~A}$ per output line. The principal components consist of a $100 \mathrm{~A}$ fused input circuit breaker, to serve as a main disconnect from the three-phase 208 $V$ source; a three-pole contactor for on-off control; a Spang three-phase to two-phase multi-tapped transformer; two 12-position tap switches to provide coarse voltage adjustment; two Spang power control units with manual adjustment potentiometers for fine voltage control; and digital meters for monitoring volts, amperes, and watts on each output circuit. The electrical power unit is connected to the four electrodes in the confinement through two output lines (\#2 AWG). An electrical schematic of the ISV Scott Tee power unit is referenced in the discussion of the electrode feed control panel in Section 2.9.

\subsection{Electrodes and feed Mechanism}

The electrodes are 2 -in. diameter graphite rods. Cutouts in the primary and secondary containment covers allow electrode separation distance to be varied between 8 and $10 \mathrm{in.}$ The electrode system includes air-operated electrode grippers and air-motor driven electrode feeders. The electrodes may be operated in either a free fall mode or in an air-motor driven mode to continually position the electrodes in the melt during the process. 


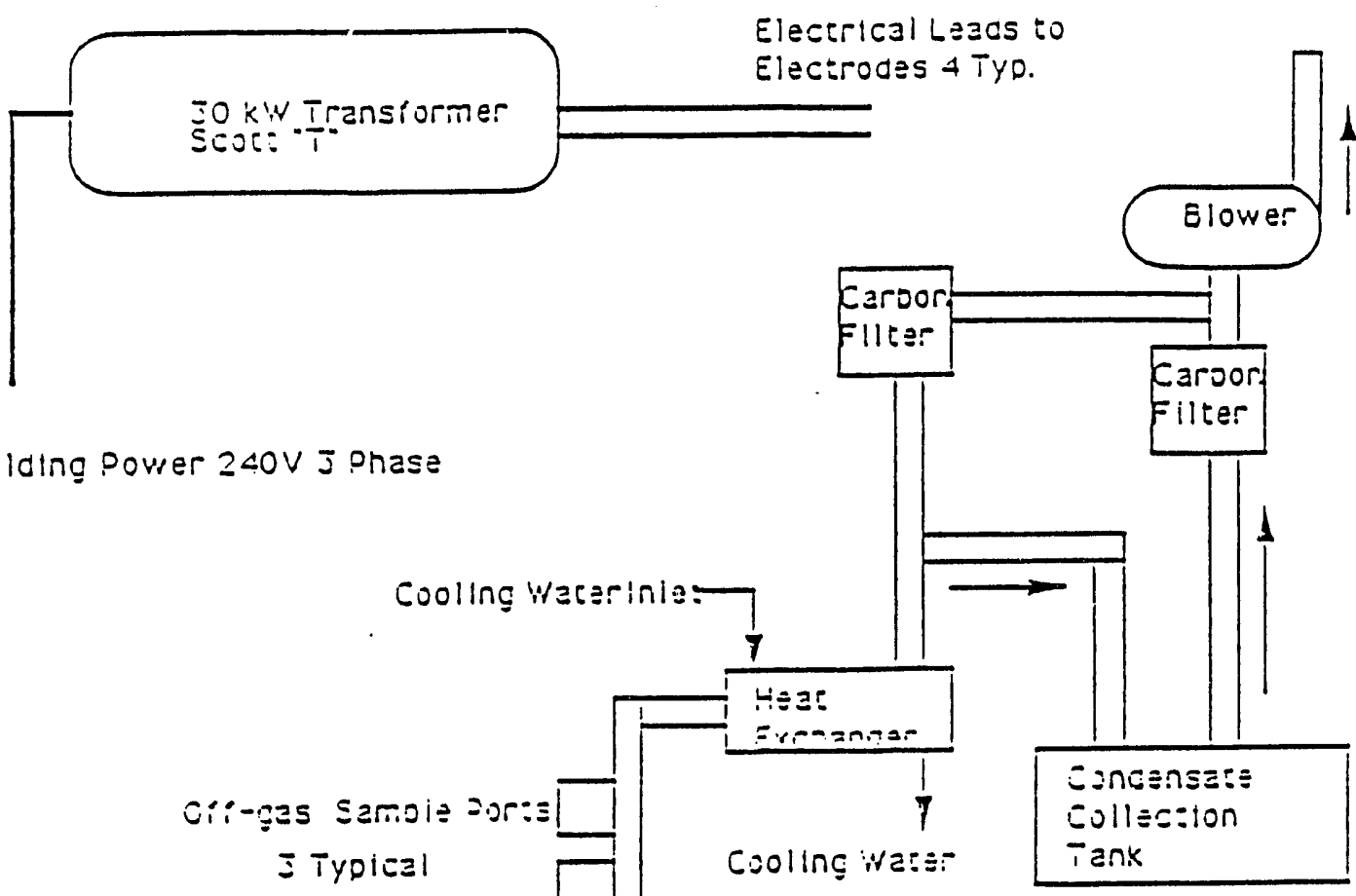

To Eullding Power 240V 2 Phase

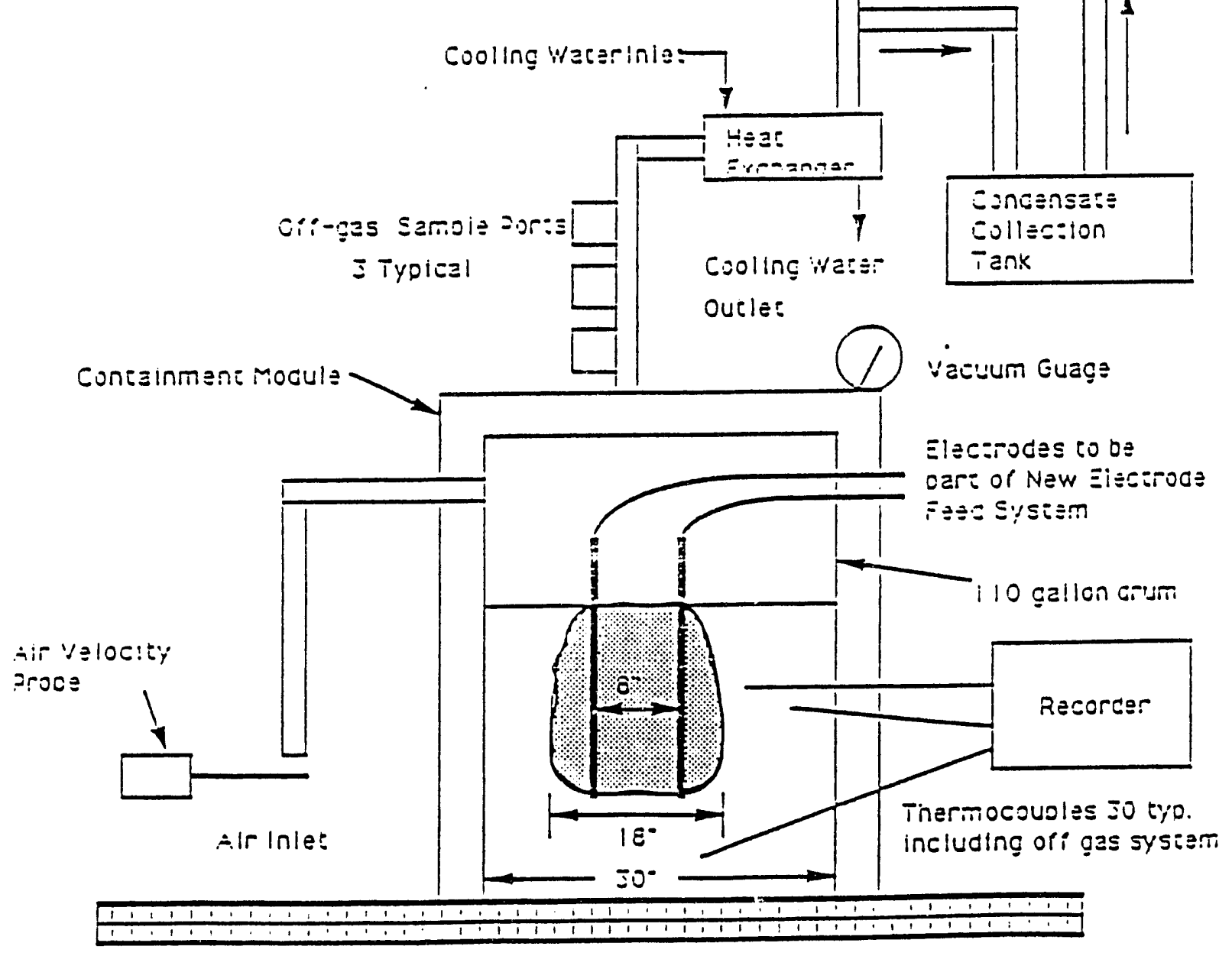

Figure 1. Engineering scale system schematic. 


\subsection{Confinement}

The secondary confinement chamber is constructed of 1/4-in. A-36 carbon steel piates and measures approximately $45 \mathrm{in}$. wide by $45 \mathrm{in}$. deep by $60 \mathrm{in}$. high. The top piate is $1 / 2-i n$. A-36 carbon steel for supporting the electrode feed system. Entry into the secondary confinement is accomplished by removing the front panel, which is bolted and clamped in piace during test operations. The top of the secondary confinement is equipped with sealed instrumentation ports. The moveable electrode system is bolted to the top plate.

The primary confinement is a 110-gallon barrel that is placed within the secondary confinement on a dolly. The dolly and barrel are wheeled into the secondary confinement via a ramp. The barrel has a cover constructed of 10-gauge carbon steel, which is clamped to the barrel with eye bolts. The confinement is equipped with screw-actuated scissor jacks for lifting the cover from the barrel. The barrel cover has holes in the top for the electrodes and for the plenum. Inlet air and off-gas exhaust lines are connected between fittings on the hood and secondary confinement chamber. Each test melt will produce approximately $100 \mathrm{lb}$ of ISV glass.

The double confinement design reduces the possibility of release of potentially hazardous off-gas constituents to the operating area in the event of an over-pressurization.

\subsection{InLeT AIR LINE}

The inlet air line is a screened 3 -in. galvanized Schedule 40 pipe outside of the building and a 3 -in. poiyvinyl chloride (PVC) Schedule 80 pipe inside the building. Near the confinement, the inlet air line branches into two 2 -in. PVC Schedule 80 pipes. One of these is the primary inlet and the other is th.e secondary inlet. Each of these lines contains an activated charcoal filter and a vacuum relief valve before entering the confinement. The purpose of the filters on the inlet lines is to filter volatile organics from the off-gas in the case of an overpressurization. The purpose of the vacuum relief valves is to prevent collapsing of the confinement vessel in the 
event of a plugged inlet line. Valves are also installed in each inlet line to provide a means for controlling inlet air.

\subsection{Primary Off-Gas Line}

The primary off-gas line connects to the primary inlet line at the secondary confinement boundary (see figure 2). The primary piping inside of the secondary confinement is Schedule 10 stainless steel (304). The transition from 2-in. to 3-in. pipe occurs at the plenum.

\subsubsection{Plenum}

The plenum is an annular assembly made up of stainless steel (304) pipe that sits on top of and extends down through the barrel cover. Inlet air is pulled through the 2 -in. inlet pipe, down through the inner pipe of the plenum, and into the barrel. Off-gas is pulled up through the outer pipe of the plenum and into the 3 -in. off-gas pipe. The 3 -in. off-gas pipe inside of the secondary confinement is connected to the plenum and to the remainder of the primary off-gas system with quick-lock couplers. Allowances have been made for thermal expansion of the pipe.

\subsubsection{Sampling Ports}

Outside of the secondary confinement, the primary off-gas piping changes to 3 -in. Schedule 40 stainless steel pipe (304) with $1501 \mathrm{~b}$ flanges. Three sampling ports are provided in the primary off-gas line. The first sampling port is located eight pipe diameters downstream of the secondary confinement outlet to allow for air flow stabilization. The three sampling ports are located to allow for the connection of three independent sampling trains. These sampling ports are sealed with blind flanges and gaskets. Immediately downstream of the sampling ports, the line is reduced to $1-1 / 2$ in. Schedule 40 stainless steel pipe (304). 


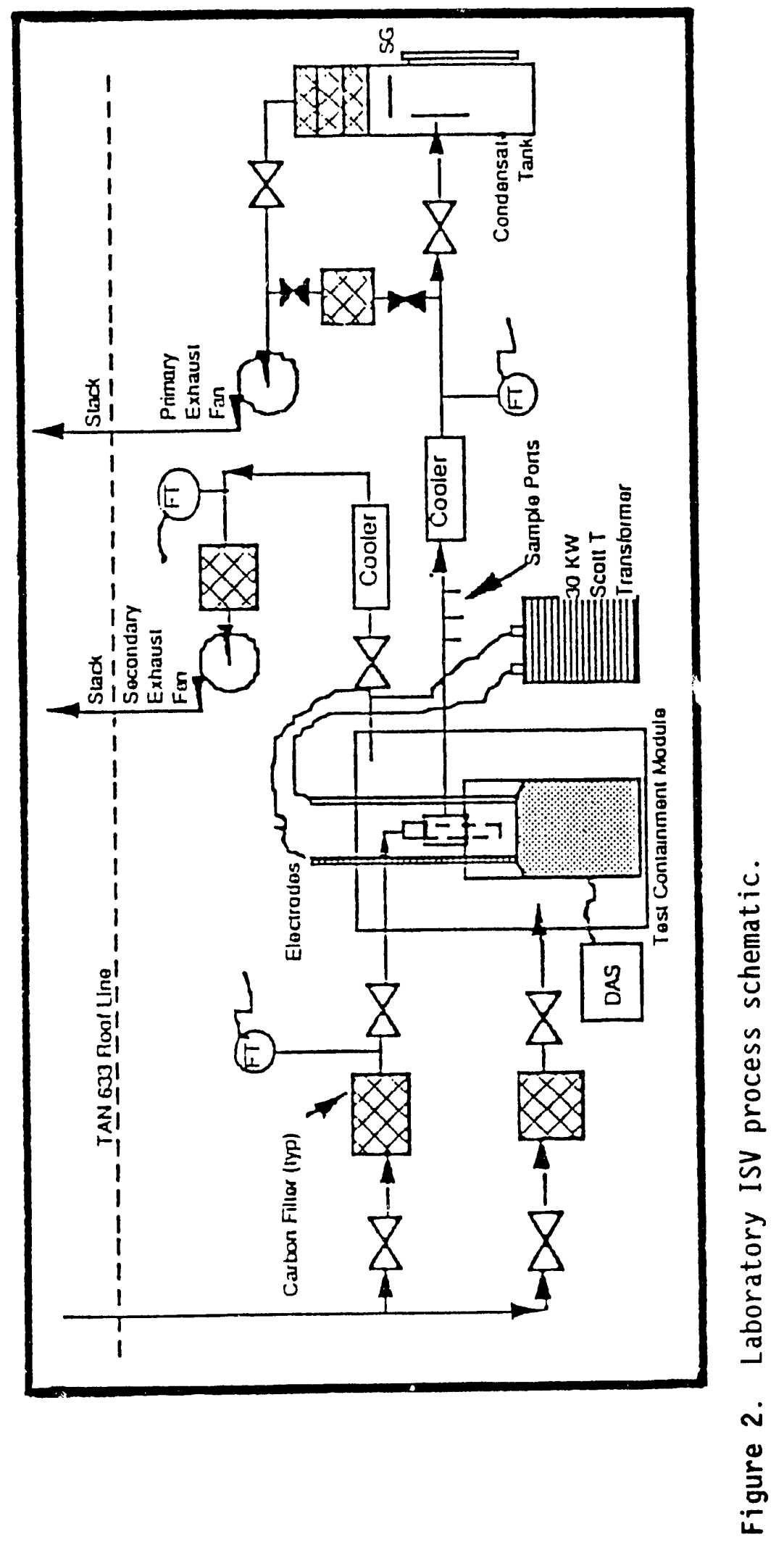




\subsubsection{Condenser}

The next component is a single pass tube-and-shell condenser with off-gas flow through the tube side and cooling water through the shell side. Cooling water flow rates are on the order of 3 to $5 \mathrm{gpm}$. This will reduce the temperature of the off-gas from a maximum of $300^{\circ} \mathrm{C}$ to approximately 30 to $35^{\circ} \mathrm{C}$. The piping then changes to PVC at this point.

\subsubsection{Condensate Collection Tank}

Next is a condensate collection tank made of 10-gauge carbon steel. This tank is approximately $15 \mathrm{in}$. square by $20 \mathrm{in}$. high, with the bottom sloped towards the drain fitting. This tank serves the following three purposes:

- It removes entrained water from the off-gas stream, which would deplete the adsorption capacity of the activated carbon filters and thereby reduce their efficiency

- It provides for the collection of water and contaminants that typically collect in the scrub tanks of a large-scale ISV system

- Analysis of the condensate provides an independent check on the results of off-gas sampling and provides information as to the type of secondary waste treatment that might be necessary.

The tank has an impingement device on the inlet side to remove entrained water. Above the impingement device are three activated carbon filters placed in series. A diffuser is installed below the filters to spread the off-gas stream more evenly across the filters. A high-efficiency particulate air (HEPA) filter is placed on top of the activated carbon filter assembly.

\subsubsection{Bypass Line}

A bypass line is provided around the condensate tank and filters. This bypass line has an activated charcoal filter similar to those used on the inlet lines. Valves are provided to direct the flow to either the condensate tank or through the bypass line. 


\subsubsection{Blower}

The blower unit is next. The blower provides the induced draft for pulling the off-gas through the primary system. This blower is a standard Grainger air handling unit with a capacity of $88 \mathrm{ft}^{3}$ at $10 \mathrm{in}$. of water. The blower unit is elevated with respect to the majority of the other piping to help ensure no moisture collects in the blower volute. This blower unit requires $110-V$ power.

\subsubsection{Exhaust Stack}

After the blower, the primary off-gas pipe transitions to galvanized pipe, leaves the building, and extends above the roof 1 ine.

\subsection{Secondary Off-Gas Line}

The secondary off-gas line begins at the outlet of the secondary confinement. This line is immediately reduced to $1-1 / 2$ in. stainless pipe and enters a condenser identical to the one in the primary off-gas line. Again the line transitions to PVC, then contains a condensate drain, filter, blower, and galvanized exhaust stack similar to those in the primary line. No condensate collection tank and associated filters are included in the vecondary off-gas line. The secondary blower provides the induced draft for pulling the off-gas through the secondary system and maintains a negative pressure inside the secondary confinement. A low point is provided in the secondary off-gas system downstream of the condenser for collection of any condensate that may form.

\subsection{INSTALLATION}

The ISV laboratory test equipment is located in Room \#9 of the Test Area North (TAN) -633 Hot Cell Annex Building (see Figure 3). The primary and secondary off-gas systems are located on a skid plate assembly separate from the containment. The electrical power, pressurized air, cooling water supply, and cooling water drain are provided in this room. 


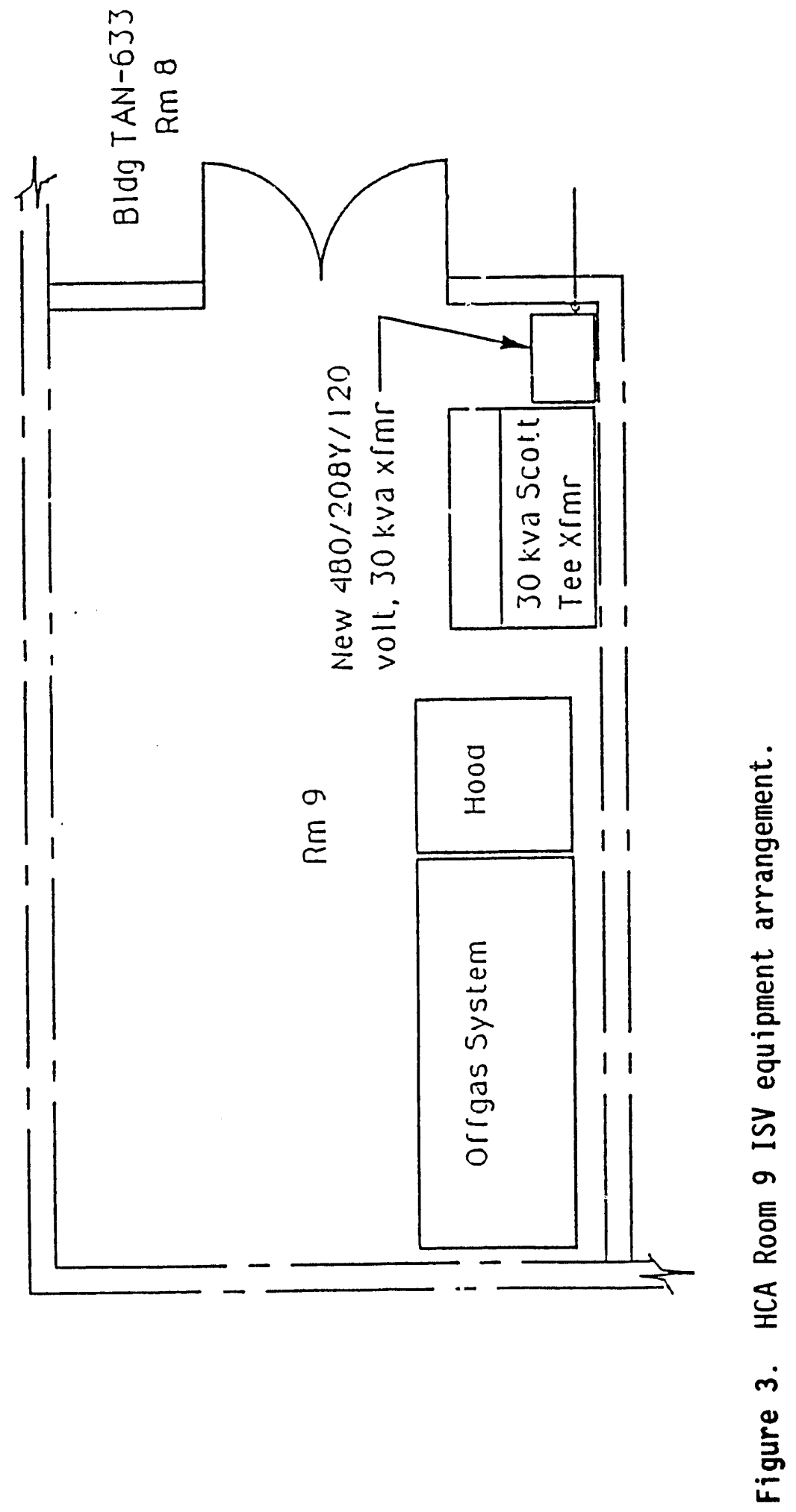




\subsection{INSTRUMENTATION}

Instrumentation components are located at various locations in the system to monitor the process. An Omega Rotameter is located on each water line to monitor cooling water flow rates. Type $K$ thermocouples and panel meters provide temperature information in the test soil, primary confinement, secondary confinement, primary off-gas at secondary confinement outlet, and primary condenser outlet. Primary and secondary confinement pressure information is provided by Validyne differential pressure transducers, demodulators, and panel meters. Primary and secondary off-gas flow rate data are provided by Dwyer flow sensors, Rosemount differential pressure transmitters, and Validyne panel meters. A continuous mercury analyzer is installed in the work area, which is set to alarm at a predetermined action level. Information from the instrumentation will be monitored and recorded by the data acquisition system (DAS).

\subsection{Electrode feed Control Panel}

The electrode feed control panel provides control for electrode position in the melt during the vitrification process (see Figure 4). This panel is constructed of 1/8-in. A-36 carbon steel and is mounted on the Scott Tee transformer cabinet.

The electrode feed control panel contains control equipment for the electrode air grippers and air drive motors. The external air supply is connected to a canister filter on the control panel inlet. The outlet of the filter is split into two air supply headers. One header is used for the electrode feed system air grippers and the other for the electrode feed system air drive motors. An air regulator is located in each header just downstream from the header split tee. Air pressure in each header is indicated on a pressure gauge located downstream from the air regulators.

Four three-way valves are installed in the air gripper header to control air to individual electrode air grippers. Four four-way valves are installed in the air drive motor control header to supply air to the air drive motors. 


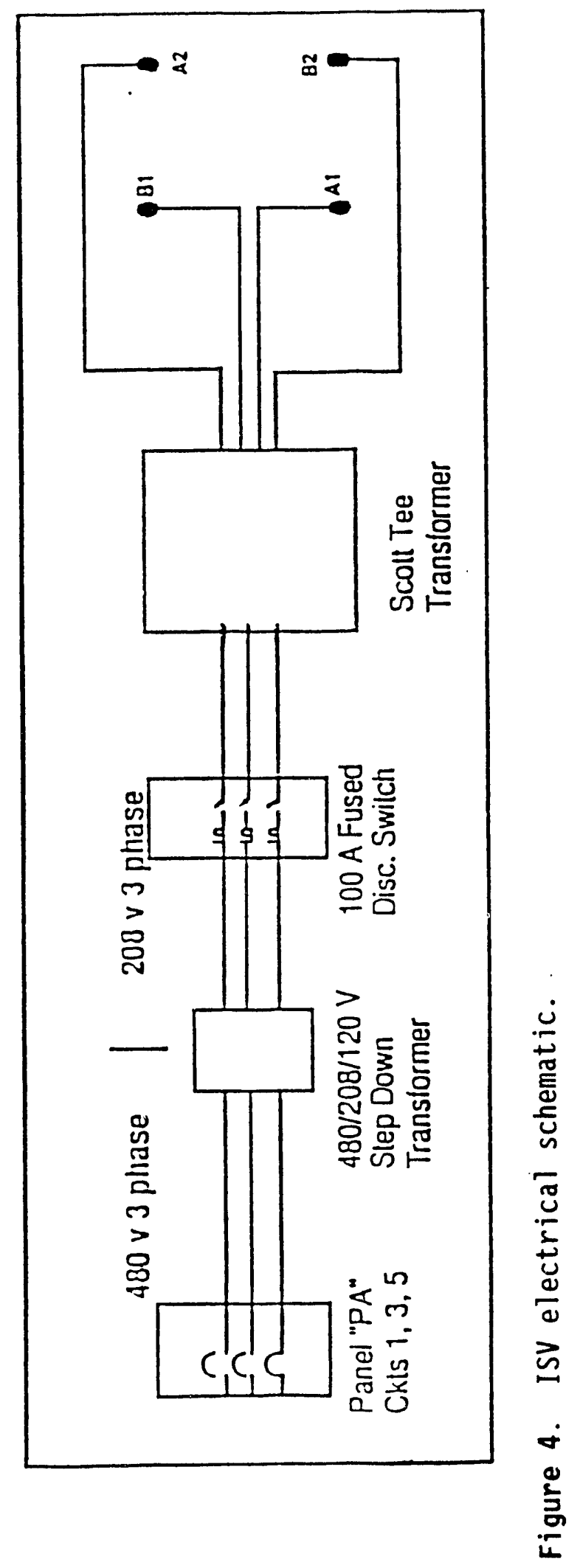




\subsection{DOCUMENTATION}

Geosafe provided the following engineering-scale drawings with the equipment:

$\begin{array}{lll}\text { G-EG\&G-2001 Sheets 1-2 } & \text { Feed System Assembly } \\ \text { G-EG\&G-2001 Sheet } 3 & \text { Driver Assembly } \\ \text { G-EG\&G-2001 Sheet } 4 & \text { Driver Assembly Details } \\ \text { G-EG\&G-2001 Sheet } 5 & \text { Containment Plates } \\ \text { G-EG\&G-2001 Sheet } 6 & \text { Control Panel } \\ \text { G-EG\&G-2001 Sheet } 7 & \text { Miscellaneous Details } \\ \text { G-EG\&G-2001 Sheet } 8 & \text { Containment Assembly } \\ \text { G-EG\&G-2002 } & \text { Off-Gas-System Assembly } \\ \text { G-EG\&G-2003 } & \text { Condensate Tank and Filter Assembly } \\ \text { G-EG\&G-2004 } & \text { Dolly Assembly. }\end{array}$

EG\&G's modifications to the engineering-scale system are documented in the following drawings:

$\begin{array}{ll}438276 & \text { ISV Equipment Pipe and Instrumentation Diagram } \\ 438277 & \text { ISV-ES Equipment Piping Assembly Installation } \\ 438278 & \text { ISV-ES Equipment Piping Assembly } \\ 438279 & \text { ISV-ES Equipment Containment and Ramp Modifications Assembly } \\ & \text { and Details } \\ 438280 & \text { ISV-ES Equipment } 2 \text { Inch Filter Assembly and 1-1/2 Inch Filter } \\ & \text { Assembly } \\ 438281 & \text { ISV-ES Equipment Pipe Support Assembly and Blower Support } \\ 438282 & \text { Assembly } \\ 438283 & \text { ISV-ES Equipment Barrel Clamp Ring Assembly } \\ 438284 & \text { ISV-ES Equipment Flange Detail and Plenum Assembly } \\ 438285 & \text { ISV-ES Equipment Barrel Cover Assembly }\end{array}$


While the term "laboratory test equipment" is now commonly used at INEL, please note that drawings and other design documentation, many previously furnished by Geosafe Corporation, still carry the designations EngineeringScale, or ES. 


\section{CONFIGURATION MANAGEMENT}

The configuration management system for the ISV Laboratory Test model uses the concept of establishing a technical baseline, controlling changes to the baseline, and documenting and reporting the change process and implementation status. This technical baseline is a configuration reference point established by approval of documents related to conduct and completion of ISV laboratory-scale testing activities. After approval and release of documents listed in this section, changes to these documents must be formally approved by the ISV Laboratory Test program/project manager and others in the original approval chain. This provides a system for correctly relating changes to the established reference point.

Document

Detailed Operating Procedure

Standard Operating Procedure

ISV Laboratory Test - Technical Baseline Description

ISV Laboratory Test - Generic Test Plan

ISV Laboratory Test - Test Procedures

ISV Laboratory Test - Design Drawings and Diagrams

ISV Laboratory Test - Site Work Releases

Quality Program Plan, QPP-149

ISV Laboratory Test - Final Safety Analysis Report

WTDD Program Management Plan

WTDD PD-2.3, Project Planning and Work Control/

Change Control Process

WTDD PD-3.1, Occurrence Reporting

WTDD PD-3.3, Configuration Management

WTDD PD-4.1, Line Management Independent Review System Procedure
Control Method

Tan Hot Shop (THS)

Document Control

THS Document Control

Waste Technology

Development Department

(WTDD) Document Control

WTDD Document Control

WTDD Document Control

Engineering Department

Document Control

THS Document Control

ERP Document Control

WTDD Document Control

WTDD Document Control

WTDD Document Control

WTDD Document Control

WTDD Document Control

WTDD Document Control 
ISV Laboratory Test - Spill Control Plan/THS Emergency Planning THS Document Contrul

ISV Laboratory Test - Waste Minimization Plan WTDD Document Control ISV Laboratory Operations Engineering Design File, WTDD Document Control Hazard Classification Quality Program Plan, QPP-132 TSH Document Control

Engineering design documenis are controlled in accordance with the requirements of applicable Engineering Standard Practices. 


\section{PROGRAM MANAGEMENT INTERFACES}

ISV Laboracory Tests Documentation Interfaces are shown in Figure 5. This figure shows the interrelationship between the Department of Energy (DOE), Environmental Protection Agency (EPA), State of Idaho, other agencies and governmental units, and EG\&G Idaho. ISV Laboratory Test interfaces with other INEL Programs and activities are also identified. The Project Management PIan is prepared under the direction of the ISV unit manager and project control using guidance from DOE-ID, DOE Order 4700.1, and the entire project scope of work as identified in the ISV Demonstration Program Long Range Project Plan.

\subsection{ISV Laboratory TESTS SUPPORT DOCUMENTATION}

ISV Laboratory Tests Support Documentation is also shown in Figure 5. This documentation is categorized into divisions which are explained in the following sections.

\subsubsection{Security Plan}

Security procedures while performing laboratory tests at TAN-633, including the requirements established in the Waste Management TAN Operations (WMTO) Tenants Manual, specifically 2.2.2 Tenants Manual/Interface Agreements and 2.2.3 Security. Security Education and Awareness Training is EG\&G Company-mandated and has been provided to ISV personnel in accordance with Section 9 of the EG\&G Safeguards and Security Manual.

\subsubsection{Quality Program Plan}

The WMTO Quality Program Plan (QPP-132) will be utilized to meet the quality assurance requirements for the management and control of ISV Laboratory Tests involving Operational quality-related activities while located at TAN-633. The Quality Program Plan utilized for management and control of ISV Laboratory Tests involving Chain of Custody quality-related activities is QPP-149. Section 6 of this document delineates the quality process and interface in ter detail. 


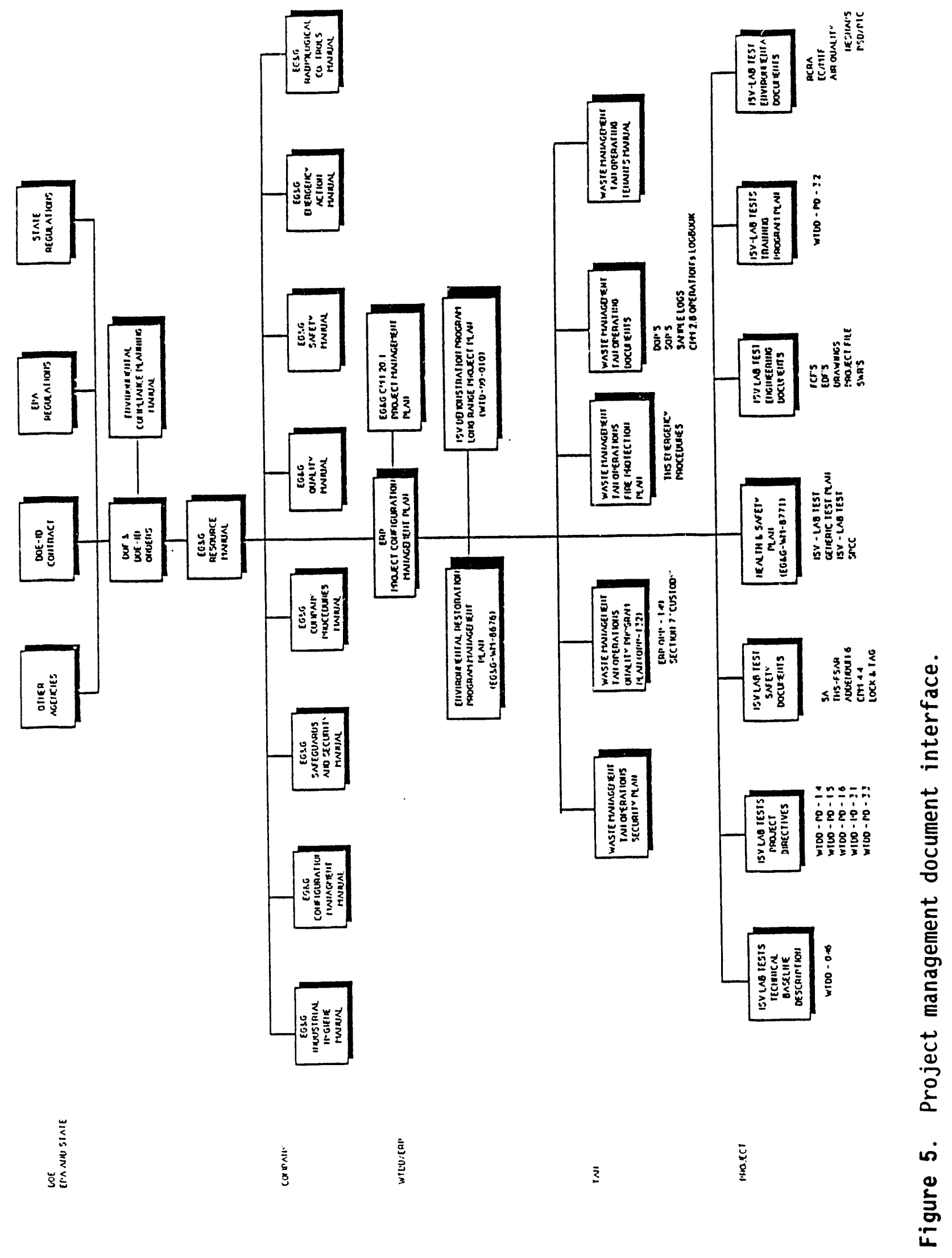




\subsubsection{Technical Plan}

This document also describes what is to be developed or constructed (see Section 2), and provides, at a higher level, engineering data to be used to meet the equipment's performance objectives. Technical coordination and engineering integration is accomplished by way of Task Baseline Agreements between the managers of individual engineering discipiines and the ISV project manager. Engineering decisions regarding design options, reflect analysis of equipment and system, cost effectiveness based on performance and other technical parameters, project schedule, resource constraints, and risk assessments. Technical reviews are conducted at formal design reviews, safety analyses, and an operational readiness review.

\subsubsection{Fire Protection Plan}

The WMTO ISV Tenants compliance requirements are further discussed in Section 5. The Fire Protection Plan identifies applicable THS Emergency Procedures.

\subsubsection{Operating Documentation}

Operating requirements are followed as delineated in the Plant Operating Manual Detailed Operating Procedures (DOPs) and Standard Operating Procedrues (SOPs) and Operating Logs. The Company Procedures Manual, criteria for Operations Logbooks, Section 2.8 is implemented through THS procedures and utilized by ISV Laboratory Tests Project.

\subsubsection{Tenants Manual}

ISV Laboratory Tests Tenants Interface Agreement as delineated in the Tenants Manual.

\subsubsection{Program Directives}

ISV Laboratory Tests administrative controls utilized for this project are defined in Waste Technology Department Directives. The applicable Project Directives are as follows: 
- PD-1.4 - Records Management Plan

- PD-1.5 - Document Preparation, Review, Approval, Management and Change Control

- PD-1.6 - Engineering Design File (Project File)

- PD-3.1 - Occurrence Reporting

- PD-3.2 - Employee Training/Required Reading Programs

- PD-3.3 - Configuration Management

- PD-4.1 - Line Management Independent Review System Procedure for WTTD.

\subsubsection{Safety Documents}

Safety Documents in addition to those implemented by the Tenants Manual and the TAN Operating requirements are Safety Assessment Addendum 6 to THS FSAR and the Company Procedures Manual, Lock and Tag requirements identified in Section 4.4 .

\subsubsection{Health and Safety Plan}

The Personnel Health and Safety PIan (EGG-WM-8771) identifies the criteria for the Waste Technology Department and is implemented through the ISV Generic Test PIan (EGG-WTD-9386) and the Spill Controls Countermeasures Plan (SPCC).

\subsubsection{Engineering Documents}

Engineering procedures list the various documents utilized in engineering controls.

\subsubsection{Training Program Plan}

Training is identified in the Training Program interface agreement letter to project file and the Waste Technology Development Department - Project Directive 3.2 . 


\subsubsection{Environmental Documents}

Environmental requirements are established in various documents such as RCRA permits, NEPA, NESHAP, PSD documents, and the Environmental Protection Plan. 


\section{SAFETY}

Safety requirements, as applicable and provided by the EG\&G Safety Manual and the Industrial Hygiene Manual will be strictly observed. SOPs, DOPs, and Site Work Requests (SWR's) are reviewed for compliance by Safety Engineering. Addendum 6 of the TAN Hot Cell Complex Final Safety Analys is Report, Section 7, reviews the ISV Laboratory Test's potential hazards and explains their prevention, or mitigation. The Operational Safety Requirements (OSR's), Safety Limits and Operating Limits are stated in detail in Section 10 of the Final Safety Analysis Report (FSAR) Addendum 6. Equipment design, operation procedures, operator training, and administrative controls will minimize environmental releases during process operations. Safety hazards are prevented or adequately mitigated to produce a safe work environment for the ISV operators. ISV processes conducted in TAN-633 will not compromise the safety of personnel in other TAN areas, or the general public.

The requirements of the WMTO fire protection plan, detailed in WMTO SD-11 and SD-5.14 apply to the ISV tenant organization. The WMTO Tenants manual, 2.3.9 Fire Protection, reiterates the requirements. 


\section{QUALITY}

Quality program requirements for the ISV project are provided by the utilization of both QPP-132 and QPP-149. QPP-132 is the WMTO document utilized for the initial installation and modification in TAN-633, Room 9 for the ISV Laboratory Test Project. This process includes the management and control of Facility Change Forms (FCFs) and Site Work Releases. QPP-149 is the Environmental Restoration Program (ERP) document utilized, prior to the reorganization of the ISV project into the Waste Technology Development Department, for the management and control of the initial procurement, design, and fabrication process on ISV equipmerit. This quality interface with programmatic work of construction/modification projects is identified in Section 4 of QPP-132. The Quality Program Plan utilized for the management and control of ISV Laboratory Tests involving Sampling/Chain of Custody quality-related activities will be QPP-149 and are detailed in the Generic Test Plan (EGG-WTD-9386), Section 4. Drawing Change Control on ISV Laboratory Test installation was managed by the Engineering Department and their applicable Standard Practices.

The Quality Level B requirements of QP-3 of the EG\&G Idaho Quality Manual are involved without exception.

NOTE: QPP-337 is currently out for review and approval. This document will be the Waste Technology Development Department's programmatic Quality Program Plan. It will replace QPP-149 in the future.

\subsection{Organizational Responsibilitees}

QPP-149 describes the responsibilities of each unit and identifies the ISV Treatment Technology as being evaluated for its applicability to INEL. The external and internal interfaces are identified in QPP-149 for ISV. The necessary interfaces between the Waste Management TAN Operations and the Waste Technology Development Department are identified in Figure 6 . Figure 7 shows the reconfigured unit organizations within the Waste Technology Development Department and the ISV Laboratory Test personnel under the Technology Development Unit. 


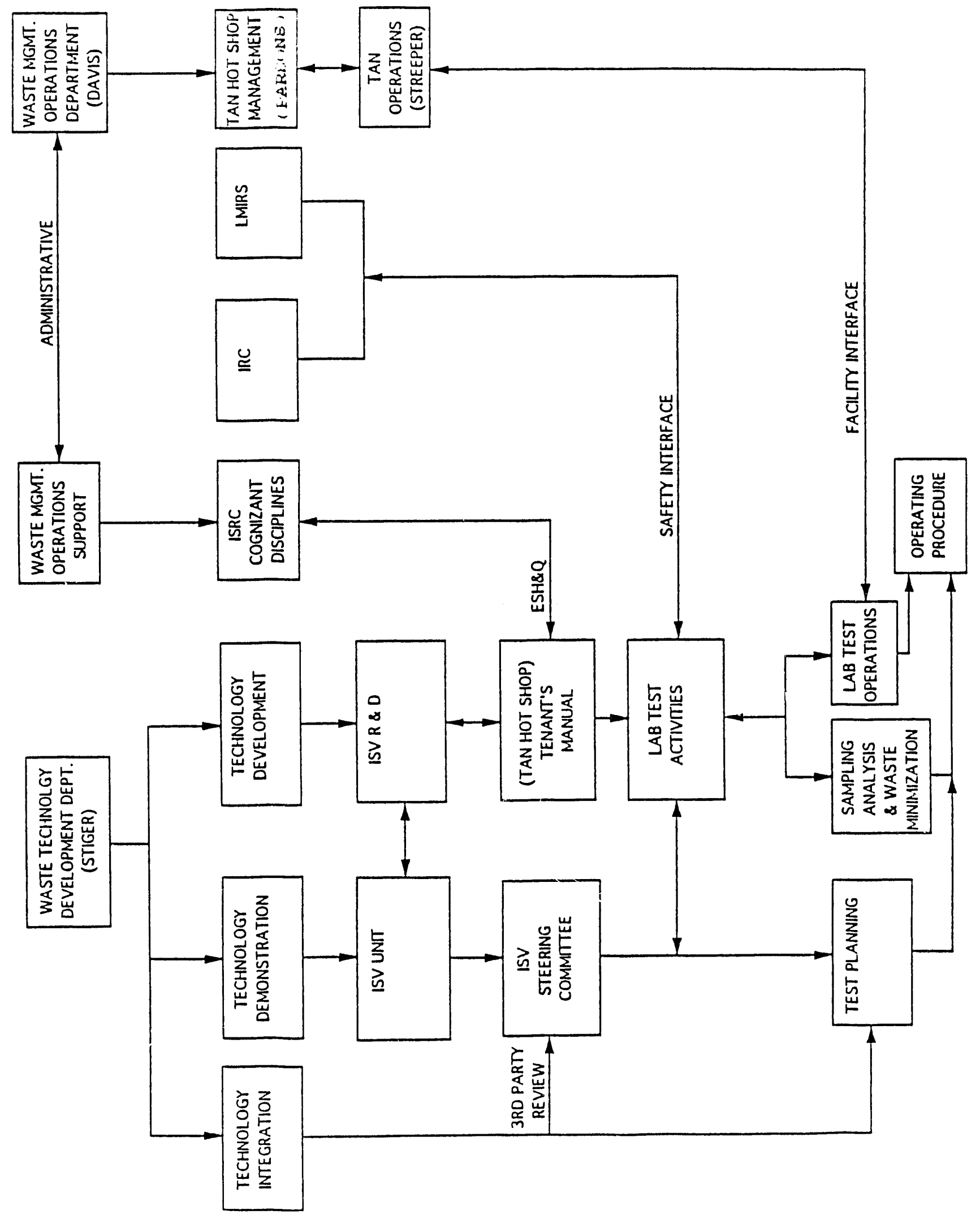

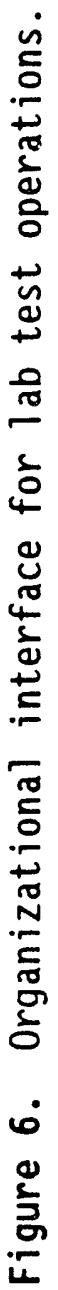




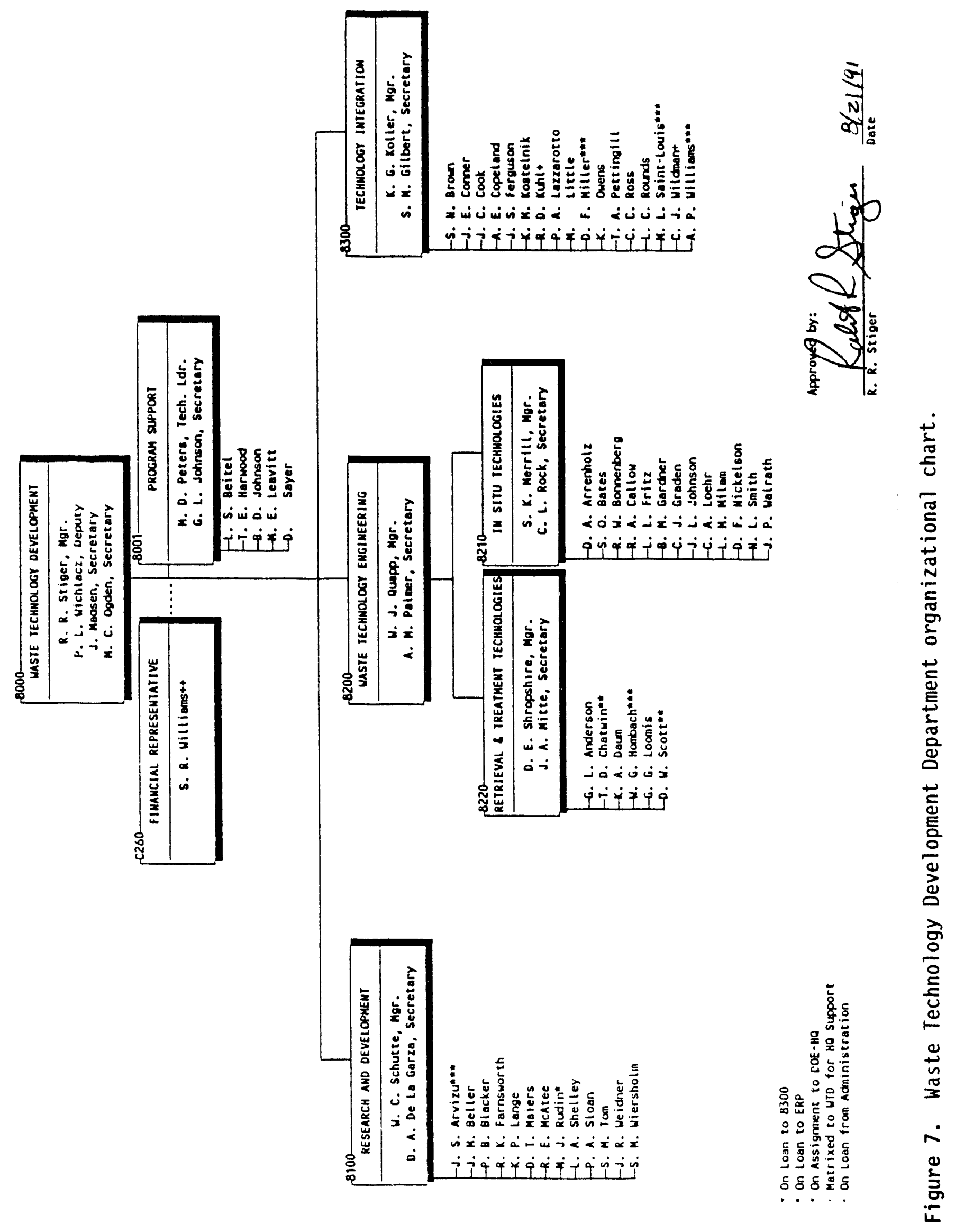




\subsection{Quality Program Elements}

Figure 8 is a matrix which identifies the Quality Program Plan, QPP-132 or QPP-149, utilized for the corresponding Quality Program Element. 


\begin{tabular}{|c|c|c|}
\hline COMPANY QUALITY PROGRAM & \multicolumn{2}{|c|}{ APPLICABLE DOCUMENT } \\
\hline ELEMENTS & $Q P P-132$ & $Q P P-149$ \\
\hline$Q P-1$ Organization & See Sec. 6 & See Sec. 6 \\
\hline QP-2 Quality Program & $\begin{array}{l}\text { A (Tan } \\
\text { Operation Only) }\end{array}$ & A \\
\hline QP-3 Design Control & $3 \& 4$ & $1 \& 2^{\star}$ \\
\hline QP-4 Procurement Document Control & $3 \& 4$ & $1,2,3,84^{\star}$ \\
\hline QP-5 Instructions, Procedures, and Orawings & $5 \& 8$ & $6 \& 7 \star$ \\
\hline QP-6 Document Control & $3 \& 8$ & $5.6 \& 7^{\star}$ \\
\hline QP-7 Control of Purchased ! tems and Services & 3 & 1 \\
\hline QP-8 Ident if ication and Control of I tems & 8 & 1 \\
\hline QP-9 Control of Processes & 8 & 7 \\
\hline$Q P-10$ Inspection & A & $N / A$ \\
\hline QP-11 Test Control & $A(D O P)$ & $\begin{array}{l}\text { A (Specific } \\
\text { Test Procedure) }\end{array}$ \\
\hline QP-12 Control of Measuring and Test Equipment & N/A & $1,6, \& 8$ \\
\hline QP-13 Handling, Storage, and Shipping & $N / A$ & $7 \& 8$ \\
\hline QP-14 Inspection, Test, and Operating Status & A & $N / A$ \\
\hline QP-15 Control of Nonconforming items & A & A \\
\hline QP-16 Corrective Action & A & A \\
\hline QP-17 Quality Records & $3,5, \& 7$ & $\begin{array}{c}5,6,7, \& 8 \\
\text { (Sampling) }\end{array}$ \\
\hline QP-18 Quality Audits & $N / A$ & A \\
\hline QP-19 Readiness Review & A & N/A \\
\hline QP-20 De leted & $\mathrm{N} / \mathrm{A}$ & N/A \\
\hline QP-21 Computer Software Configuration Management & $N / A$ & $A$ \\
\hline
\end{tabular}

\section{LEGEND}

1 - Procurement 2 - Design 3 - Modification 4 - Installation

5 - Inspection 6 - Testing 7 - Sampling 8 - Operation

* Engineering Department Standards Practices for Drawings

A - Applicable N/A - Not Applicable

Figure 8. Company quality program matrix. 


\section{CONDUCT OF OPERATIONS MATRIX \\ DOE 5480.19}

ORDER ATTACHMENT I CATEGORY

I. Organization and Administration

II. Shift Routines and Operating Practices

III. Control Area Activities

IV. Communications

v. Control of On-shift Training

VI. Investigation of Abnormal Events

VII. Notifications

VIII. Control of Equipment and System Status

IX. Lockout/Tagout
IMPLEMENTING DOCUMENT(S)

Waste Technology Development Department Program Directives

Tenants Manual

ISV Generic Test Plan

Facility Preventative Maintenance Specific Laboratory Procedures

Tenants Manual

Specific Laboratory Procedures

Facility Emergency Manual/RCRA Contingency Plans

ISV Spill Prevention, Control and

Countermeasures $\mathrm{Plan}$

WTDD Program Directive - 2.2

ISV Training Program Plan

WTDD Program Directive - 3.2

Safety Manual, Section 3

ISV Spill Prevention, Control and Countermeasures Plan

WTDD Program Directive - 3.1

Facility Emergency Manual/RCRA

Contingency Plans

ISV Spill Prevention, Control and

Countermeasures Plan

Specific Laboratory Procedures

Company Procedures Manual, Sec. 4.4

(Lock and Tag Procedure), Sec. 2.5

(Work Control Procedures), and

Sec. 2.8 (Operation Log Keeping).

Company Procedures Manual, Sec. 4.4 (Lock and Tag Procedure), Safety Manua 7, Section 7, and Tenants Manual. 
ORDER ATTACHMENT I CATEGORY

$X$. Independent Verification

XI. Logkeeping

XII. Operations Turnover

XIII. Operations Aspects of Facility Chemistry and Unique Processes

XIV. Required Reading

XV. Timely Orders to Operators

XVI. Operations Procedures

XVII. Operator Aid Postings

XVIII. Equipment and Piping Labeling
IMPLEMENTING DOCUMENT(S)

Specific Laboratory Procedures and WTDD Program Directive - 3.2

Company Procedures Manual, Sec. 2.8 (Operation Log Keeping).

Tenants Manual

ISV Generic Test Plan

Quality Program Plan - 149, Sec. 7 (Sample Custody).

Company Procedures Manual, Sec. 2.5 (Work Control Procedures)

ISV Generic Test Plan

ISV Training Program Plan

Tenants Manual

ISV Generic Test PIan

Specific Laboratory Procedures

Company Procedures Manual, Sec. 2.3

(Required Reading Programs).

WTDD Program Directive - 3.2

Specific Laboratory Procedures

WTDD Program Directive - $1.2 \& 1.5$

Company Paging System

Written Memos

Company Procedures Manual, Sec. 2.5 (Work Control Procedures), Sec. 2.7 (Use of Drawings), and Sec. 2.9

(Control of Alarms).

Safety Manual, Section 2

WTDD Program Directive- $1.2 \& 1.11$

Specific Laboratory Procedures

ISV Training Program Plan - Lesson Plan to be developed.

Safety Manual, Section 12 

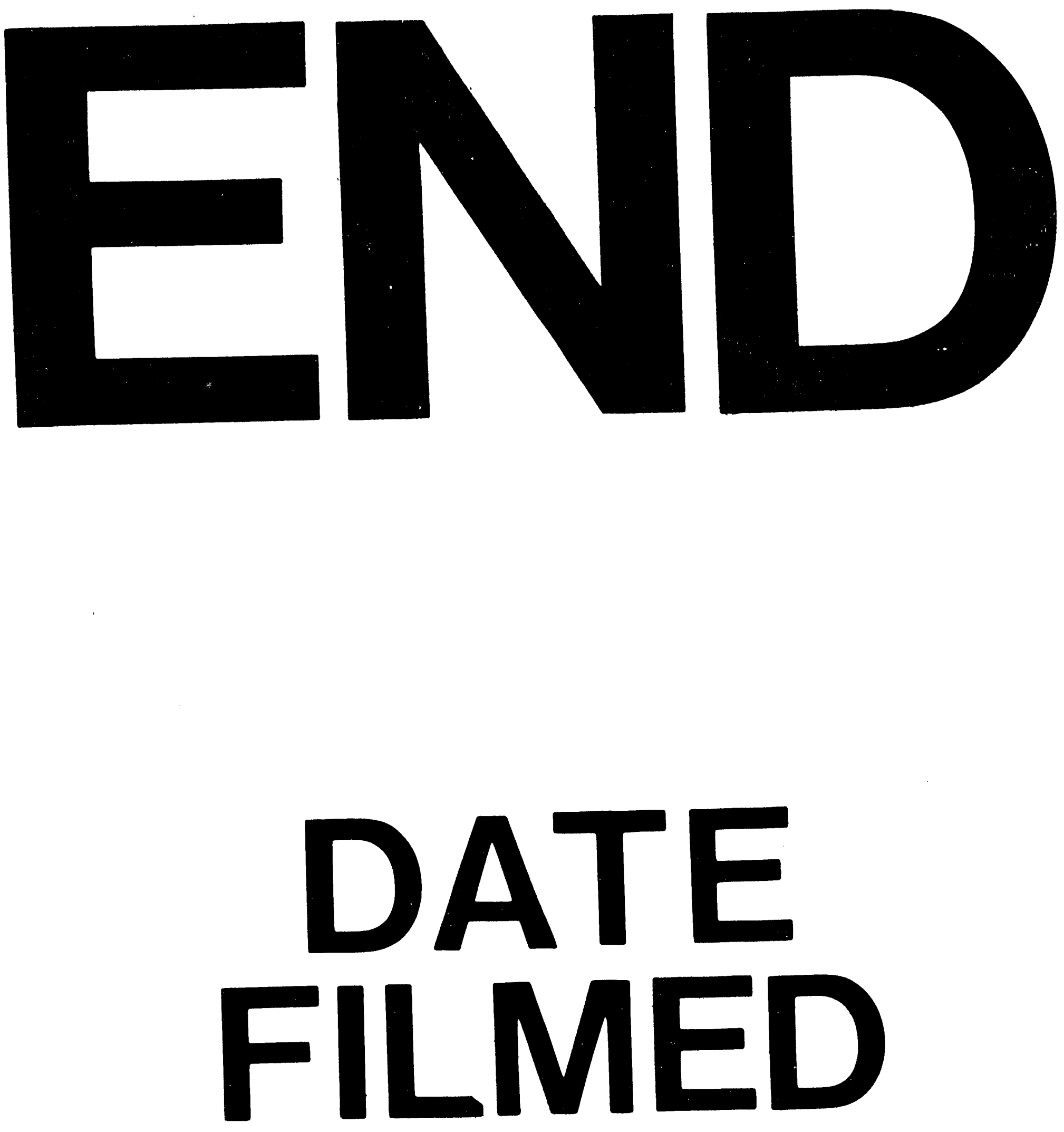

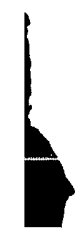

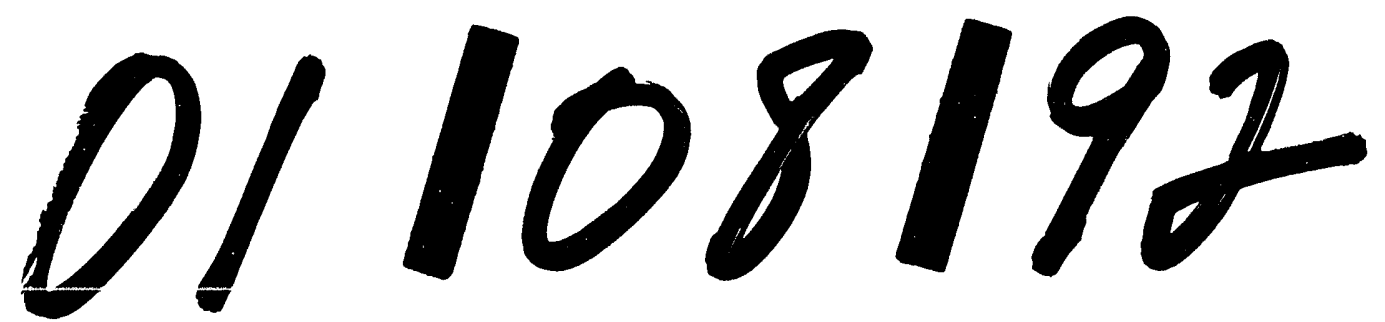


